\title{
Status of Raso Lark Alauda razae with notes on threats and foraging behaviour
}

\author{
NORMAN RATCLIFFE, LUIS R. MONTEIRO and CORNELIS J. HAZEVOET
}

The Raso Lark Alauda razae is a globally endangered species that is endemic to the islet of Raso $\left(16^{\circ} 93^{\prime} \mathrm{N}, 24^{\circ} 38^{\prime} \mathrm{W}\right.$ ) in the Cape Verde archipelago (Collar et al. 1994). Raso is a small (c.7 $\mathrm{km}^{2}$ ) uninhabited islet with a plain averaging $25 \mathrm{~m}$ in elevation to the south and west and small boulder-strewn hills to the north and east rising up to $164 \mathrm{~m}$ (Figure 1 ). The islet comprises mostly rocky desert, with some extensive sandy patches on the western plain. Vegetation is sparse and confined to small patches on the plains and along dry river valleys.

A complete census of the Raso Lark population was conducted on 11 February 1998. The western half of Area 1 (see Figure 1) was searched systematically by three observers walking slowly along a series of contiguous 30-m-wide transects. This demonstrated that Raso Larks were associated exclusively with small vegetated patches and so the survey of the rest of the islet concentrated on systematically locating these habitat patches and counting the number of larks associated with them.

Raso Larks were found in the localities shown in Figure 1, with 37 birds on the plains around Chã Brancà, Chã do Castelo, and Chã de Posende (area 1), 5 along Ribeira do Preto Pesqueiro (area 2), 22 on the plateau between the hills of Lombo Sustem and Monte de Selada (area 3) and 28 in the area to the south of Ribeira do Ladrão (area 4), i.e. a total of 92 birds. Ninteenth century reports suggested that Raso Larks were far commoner and more widespread at that time (Alexander $1898 \mathrm{a}, \mathrm{b}$ ). No other information on Raso Lark numbers is available until the mid-1960s to the early 1980 s when the population was between 20 and 50 pairs (Table 1). Since 1985 the population appears to have increased to between 100 and 120 pairs (Table 1). The count in 1998 suggests that the population has now declined to around 45 pairs, levels similar to those found in the 1960s. However, it is possible that some of the low counts in the 1970s and early 1980 s were not complete censuses of the whole islet (Hazevoet 1995). We would encourage any ornithologists visiting Raso in the future to conduct a complete census of the islet to ensure comparability with previous counts.

The population fluctuations described above appear to be related to droughts, with breeding being sporadic in the absence of rainfall (Hazevoet 1995). During the February 1998 census, the extent of vegetation was greatly reduced compared with that in March 1992 (Hazevoet 1995: Plate 22) and what remained was dead and desiccated. Despite March being consistently recorded as the Raso Lark breeding season (Hazevoet 1995), no evidence of breeding being initiated was apparent in mid-February 1998. It seems likely that a drought over successive breeding seasons has inhibited Raso Lark reproduction and possibly increased 


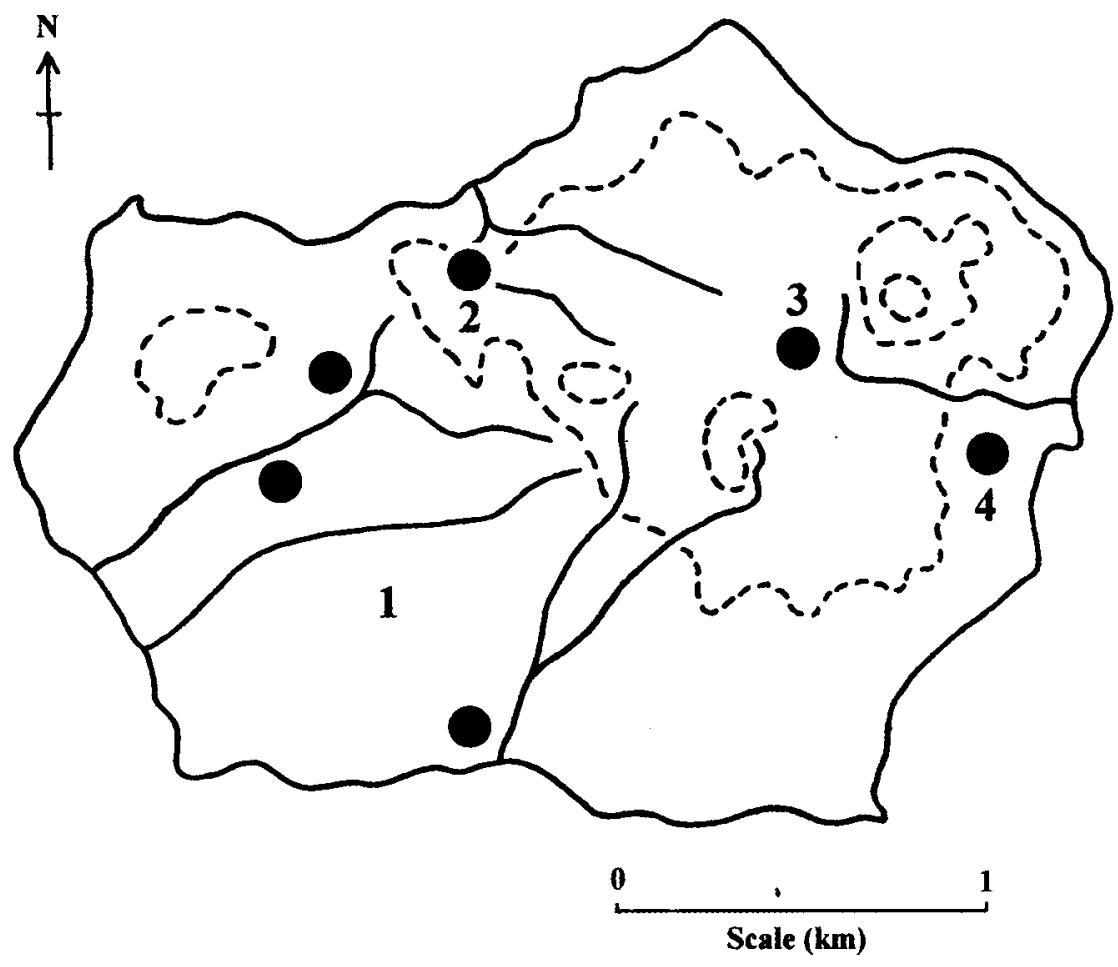

Figure 1. Map of Raso Islet showing the approximate locations of Raso Lark sightings (black circles) and the areas described in the text. Solid lines represent dry river beds, dotted lines are contours with a 50-m interval.

Table 1. Summary of numbers of Raso Larks counted during censuses from 1965-1998

\begin{tabular}{lccc}
\hline Number & Month & Year & Source \\
\hline <50 pairs & October & 1965 & de Naurois (1969) \\
<40 pairs & March & 1968 & de Naurois (1969) \\
20 pairs & August & 1977 & H.-H. Schleich, in Hazevoet (1995) \\
20 birds & June & 1981 & N $\phi r r e v a n g$ and den Hartog (1984) \\
20 pairs & October & 1981 & H.-H. Schleich, in Hazevoet (1995) \\
>150 birds & March & 1985 & Anonymous (1985) \\
75-100 pairs & March & 1986 & Hazevoet (1989) \\
200 birds & August & 1986 & den Hartog (1990) \\
$75-100$ pairs & January & 1988 & Hazevoet (1989) \\
250 birds & October & 1988 & Hazevoet (1995) \\
200 birds & January & 1989 & K.M. Morgan, in Collar et al. (1994) \\
250 birds & March & 1990 & Hazevoet (1995) \\
250 birds & March & 1992 & Hazevoet (1995) \\
92 birds & February & 1998 & This study \\
\hline
\end{tabular}


mortality rates, resulting in the reduced numbers in 1998 compared with 19861992. Given the sensitivity of the Raso Lark population to drought, long-term desertification in Cape Verde is clearly a major threat to this species.

Raso Larks were observed digging pits and tunnels (up to $8 \mathrm{~cm}$ deep) in the soil with their bills to gain access to food (as also documented by den Hartog 1990). This appeared to be the most common feeding method, and their excavations honeycombed the foraging areas. Raso Larks have also been observed using their bills to move stones while foraging (R.P. Martins and M. Beaman in Cramp 1988). These foraging methods probably allow Raso Larks to survive extended periods of drought when surface food is scarce.

Cat Felis catus faeces were found around several of the Raso Lark feeding areas in area 1. A total of 80 faeces were collected and feathers were dissected from them. These were compared with feathers on specimens in the Natural History Museum (Tring, U.K.) to identify the bird species upon which the cat(s) had been feeding. No Raso Lark feathers were found, while $57 \%$ of faeces contained feathers only from Red-billed Tropicbirds Phaethon aethereus, $13 \%$ contained only feathers from unidentified petrels, $11 \%$ contained feathers of both types and $19 \%$ contained no feathers. The corpses of 30 Bulwer's Petrels Bulweria bulwerii and five Madeiran Storm Petrels Oceanodroma castro showing signs of cat predation were also located in Ribeira do Ladrão.

No cats were seen during the three days and two nights we were on Raso and none of the signs of cat activity appeared fresh, so perhaps they are no longer present on the islet. However, given the impact on the regionally important seabird population and the potential for predation to reduce the Raso Lark population, further investigations into cat activity on Raso Islet are recommended. The risk of cats being introduced is constant despite the islet being uninhabited because fishermen regularly visit it to catch seabirds for food and sometimes bring and release domestic animals.

Raso Lark is listed as Endangered in Collar et al. (1994) on the basis that the population is less than 250 individuals and the range is less than $100 \mathrm{~km}$ (Category D1, D2). However, the extent of Raso Lark occurrence is less than 10 $\mathrm{km}^{2}$ and the population is subject to fluctuations, some of which may have resulted in the population being below 50 mature individuals. According to the criteria in Collar et al. (1994) we believe Raso Lark satisfies the criteria for being classed as a Critically Endangered species under Category B3d.

\section{References}

Alexander, B. (1898a) An ornithological expedition to the Cape Verde Islands. Ibis (7) 4: 74-118.

Alexander, B. (1898b) Further notes on the ornithology of the Cape Verde Islands. Ibis (7) 4: 277-285.

Anonymous (1985) Several species alive and well on Cape Verde Islands. World Birdwatch 7: 4 .

Collar, N.J., Crosby, M.J. and Stattersfield, A.J. (1994) Birds to watch 2: the world list of threatened birds. Cambridge, U.K.: BirdLife International (Birdlife Conservation Series 4).

Cramp, S., ed. (1988) The birds of the western Palearctic, 5. Oxford: Oxford University Press. de Naurois, R. (1969) Notes brèves sur l'avifaune de l'archipel du Cap-Vert. Faunistique, endémisme, écologie. Bull. Inst. Fond. Afr. Noire (A) 31: 143-218. 
den Hartog, J.C. (1990) Birds of the Cape Verde Islands: notes on species observed (9 August-10 September 1986), distribution, migration, status, origin and conservation.Cour. Forsch.-Inst. Senckenberg 129: 159-190.

Hazevoet, C.J. (1989) Notes on behaviour and breeding of the Raso Lark Alauda razae. Bull. Brit. Orn. Club 109: 82-86.

Hazevoet, C.J. (1995) The birds of the Cape Verde Islands. Tring: British Ornithologists' Union ( Checklist 13).

Nørrevang, A. and den Hartog, J.C. (1984) Bird observations in the Cape Verde Islands (4-22 June 1981). Cour. Forsch.-Inst. Senckenberg 68: 107-134.

\section{NORMAN RATCLIFFE}

Royal Society for the Protection of Birds, The Lodge, Sandy, Beds. SG19, 2DL, U.K.

LUIS R. MONTEIRO

Departamento de Oceanografia e Pescas, Universidade dos Açores, 9900 Horta, Açores, Portugal.

\section{CORNELIS J. HAZEVOET}

Museu e Laboratório Zoológico e Antropológico (Museu Bocage), Rua da Escola Politécnica 58, 1250 Lisboa, Portugal. 